\title{
Malaysian Contractors in Gulf Construction: A Preliminary Study on Financial and Economic Risks
}

\author{
Siaw Chuing Loo and Hamzah Abdul-Rahman
}

\begin{abstract}
Middle East possesses a strong spending power that few other economies can contest, presenting a greater medium to long-term opportunities than most other parts of the world, albeit the downturn in Dubai. The aim of this paper is to investigate how Malaysian contractors manage financial and economic risks when operating in the Gulf construction industry. The data collection method was face-to-face in-depth interviews with three experts from Malaysia whom had experiences in Gulf construction industry. This paper identified the financial and economic risks encountered by the Malaysian contractors and their risk response measures. From the findings, it was obvious that the Gulf economies encouraged ventures from foreign firms but the risks faced by those firms were mostly on the internal financial aspects. The findings were purely an indication on the risk management practice in the Gulf based on three in-depth interviews with Malaysian experts in the Gulf construction. This preliminary study did not involve construction projects from all countries in the Gulf region; it covered only Saudi Arabia, Qatar, United Arab Emirates (UAE) and Bahrain, but left out Oman and Kuwait due to the absence of their projects awarded to Malaysian contractors.
\end{abstract}

Index Terms-Economic risk, financial risk, international and overseas construction, risk management.

\section{INTRODUCTION}

The pressures of globalisation have generated more opportunities for construction firms to enter the international construction markets. It is noteworthy that international projects involve not only the uncertainties that arise in domestic construction projects but also those from the complex risks that are particular to international transactions $[1,2,3]$. Hence, international projects have a high possibility of loss since they are exposed to more diverse and complex risks than domestic projects. For instance, international construction is more susceptible to regional conditions like currency devaluation, currency exchange restrictions, cultural differences, or unstable laws or regulations [1]. Owing to the uncertainties and complexities associated with the international construction domain, the entry decisions for international construction markets are intricate.

In this research, the international construction market to be focused is the Middle East. According to the statistics provided by the Construction Industry Development Board (CIDB) [4] in Fig. 1, fifteen out of twenty-one overseas projects are from the Gulf, the highest number of projects being awarded from the overseas market in year 2009. These

Manuscript received May 23, 2012; revised June 18, $2012 .$.

The authors are with the Quantity Surveying Department, Faculty of Built Environment, University of Malaya, 50603 Kuala Lumpur, Malaysia (e-mail: siawchuing@um.edu.my; arhamzah@um.edu.my). countries are namely Qatar, Saudi Arabia, and United Arab Emirates (UAE). Besides, this study does not focus on a particular country because the Middle East and North Africa (MENA) countries share similarities in the geographical, cultural, and economic aspects [5]. The Gulf shares the similarities of being a resource rich and labour importing region [6].

The specific objectives of this research are: (1) to identify the types of financial and economic risks Malaysian contractors face; and (2) to investigate how Malaysian contractors manage these risks. The scope of this study is confined to the financial and economic risks faced by the Malaysian contractors undertaking construction projects in the Gulf.

In this study, financial and economic risks are being studied due to the event of Dubai World struggling to repay its debts totaling to USD $\$ 60$ billion. Following this, some Malaysian construction companies had either pulled out or were at the tail-end of completion of projects. Hence, the experiences of those Malaysian contractors dealing with the financial and economic risks when undertaking Gulf projects are investigated. The findings may provide some indications on the scenario there for both the novice and experienced Malaysian entrants.

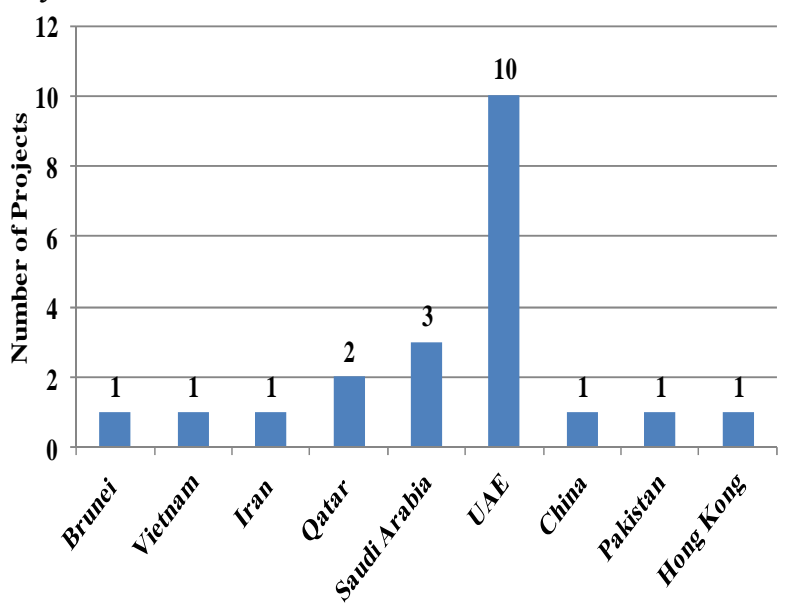

Fig. 1. Number of projects undertaken by Malaysian contractors in global market awarded in year 2009

\section{FINANCIAL AND ECONOMIC RISKS}

In this paper, the international or overseas construction projects are involved, hence, the risks are classified based on the internal and external aspects as set forth by Zhi [7]. The literatures reviewed are specified on researches studying risk management for both local or domestic and international or overseas construction projects. Note that the subsequent literature review on the financial and economic risks is 
presented in paragraphs portraying chronological order ranging from 1985 till 1999, 2000 till 2004, and 2005 till 2009 , and the risks identified by a few past researchers have been reorganized into internal and external risks.

\section{A. Internal Risk- Financial Aspect}

In 1985, Perry and Hayes identified three financial risks, which influence contract strategy on overseas construction contracts, namely 'delay in payment', and the remaining two to be mentioned under economic risks in this paper [8]. Mustafa and Al-Bahar (1991) included 'availability of funds from client' and 'financial default of subcontractor' in the proposed risk classification scheme for the study of project risk assessment using the analytic hierarchy process (AHP) [9].

Wang, Tiong, Ting, and Ashley (2000) identified a financial risk associated with the international build-operate-transfer (BOT) projects that is 'interest rate' [10]. Egbu and Serafinska (2000) listed another two risks under the financial category; 'inadequate financial margins' and 'unbalanced sharing of risks' [11]. Discussing approaches for entry decision into international projects, Han and Deikmann (2001a; 2001b) included 'burden of financing' risk in their revised risk breakdown structure $[12,1]$. In 2002, Tchankova studying the basic stage of risk identification in risk management has mentioned that economic risk at a local level, which indicates the financial risk, consists of 'interest rate' and 'credit policy' [13].

Later in 2005, Bing, Akintoye, Edwards, and Hardcastle proposed three financial risks via their study, such as 'interest rate volatility', 'availability of finance', and 'high finance costs' [14]. Through a research on construction projects in India undertaken by Singapore firms, Ling and Hoi (2006) found a few financial risks through literatures like 'interest rates', 'capital supply', 'cash flows and rentals', and cash flow problem of client' [15]. In the following year, a study on the foreign firms' financial and economic risk in China identified four financial risks, namely 'interest rate fluctuation', 'financial failure', 'no or delayed payment', and 'contractors or subcontractors' default' [16]. A survey conducted by El-Sayegh (2008) to identify and assess the significant risks in the United Arab Emirates (UAE) construction industry has identified two financial risks'delayed payment' and 'sudden bankruptcy' [17].

Having reviewed the literatures, these risks are being consolidated in accordance with the repetitive meanings, then renamed to come up with eight financial risks.

\section{B. External Risk- Economic Aspect}

Perry and Hayes (1985) identified two economic risks associated with overseas construction projects; they are 'inflation' and 'availability of and fluctuation in foreign exchange' [8]. In 1991, Mustafa and Al-Bahar proposed a risk classification scheme, which includes economic risks such as 'inflation', 'exchange rate fluctuation' and 'non-convertibility' [9].

Similarly, in 2000, Wang, Tiong, Ting, and Ashley found two economic risks associated with BOT scheme projects including 'inflation' and 'foreign currency exchange rate' [10]. Egbu and Serafinska (2000) also listed 'cost inflation' and 'currency fluctuations' under economic risk category [11]. Han and Deikmann (2001a; 2001b), who revised the risk breakdown structure by Ashley and Bonner (1987), incorporated recurring economic risks as the past researches, for instance 'currency exchange' and 'inflation' [12,1]. Tchankova (2002) cited an example of economic risk is 'economic recession and depression' [13]. Baloi and Price (2003) summarized the economic related global risk factors comprising 'inflation', 'exchange rate' and 'price fluctuation' [18].

A study on allocation of risk in public private partnership (PPP) and private finance initiative (PFI) procurements has categorized 'inflation rate volatility' and 'poor financial market' under the economic aspect [14]. A research on Singapore based firms venturing into construction projects in India identified few economic risks such as 'materials supply', 'labour supply', 'equipment availability', 'inflations' and 'exchange rates' [15]. Three economic risks are found through a study on foreign firms' financial and economic risk in China comprising 'foreign exchange fluctuation', 'inflation' and 'labour and material price fluctuation' [16]. Delving into the assessment and allocation of risk in the UAE construction industry, El-Sayegh (2008) identified a number of economic risks relating to 'inflation', 'currency fluctuation', 'shortage in material availability', 'shortage in manpower availability' and 'shortage in equipment availability’ [17].

Having reviewed and merged the repetitive meanings of the economic risks from the related past researches, four economic risks are presented for the preparation of survey.

\section{C.Knowledge Gap}

To the best of the authors' knowledge, few have researched on risk management for Malaysian contractors venturing into overseas or international projects while fewer have researched on Malaysian contractors working on construction projects in the Gulf. Therefore, this preliminary study attempts to fill the gap by interviewing three construction firms venturing in the Gulf to investigate the financial and economic risks faced and the risk response measures taken by them.

\section{RESEARCH METHODOLOGY}

This study employs a mixed methods survey strategy with a concurrent transformative design introduced by Creswell [19]. To do so, a questionnaire survey is most practical and suitable for this study because it can be the combination of both quantitative and qualitative. Since the research involved probing of open-ended questions, in-depth face-to-face interview was employed so that thorough perspectives of the interviewees were clarified, discussed and captured.

Having collected the data such as the risks encountered and the risk response measures exercised, they were analyzed using content analysis because large portions of the data were descriptive. Krippendorff (1980) explains that content analysis is a research technique for making replicable and valid references from data to their contexts [20].

The survey was conducted from February to March 2010 targeting a population comprised of Malaysian contractors 
with experience undertaking construction projects in the Gulf. Prior to conducting the interview, pilot studies were carried out with two academics and one contractor to ensure the questionnaire on clarity, unambiguousness, and of layman terms. According to the directory of Malaysian contractors registered for international projects, twenty-one contractors had experience working in the Gulf [21]. In this preliminary study, only three contractors were selected to be interviewed and the questionnaires were emailed to the targeted contractors prior to the interview sessions.

\section{Profile of Interviewees AND Their Projects}

The profile of the interviewees is depicted in Table I. The years of experience in the construction industry of the interviewees ranged from 9 to 25 years, with a mean of 18 years. These three public limited construction firms operated in the Gulf between 3 to 8 years, which signified an average of 5.3 years. The profile of the Gulf construction projects undertaken by the interviewees' construction firms is shown in Table II.

\section{RESULTS AND DISCUSSION}

Based on the preliminary study, financial and economic risks encountered by the Malaysian construction firms in the Gulf are described alongside the risk response measures adopted.

\section{A. Internal Risk- Financial Aspect}

1) Interest rate volatility

According to $\mathrm{C} 1$ and $\mathrm{C} 3$, they were self-financed when engaged in the Gulf construction projects. This signified that both construction firms generated their growth capital from their own income rather than attaining them from external sources like investors or lenders or financial institutions. Contractors had also secured an advance payment from the employer, which was ten percent of the contract sum within a fixed period of time following the execution of contract. Meanwhile, C3 mentioned that the interest rate had temperate impact on the projects due to moderate borrowing from the financial institution. C3 further explained that the interest rate had remained steady throughout their execution of projects in the Gulf. It is implied that contractors, who are self-financing in their overseas projects, need to be financially robust by setting aside sufficient sum of internal reserve funds.

\section{2) Cash flow}

The cash flow risk is loss due to a mismatch between cash inflows and outflows. Both C2 and C3 were faced with cash flow crunches during the course of the Gulf construction projects. Due to limited internal funding, C2 managed the cash flow problem through the banking facilities like export credit refinancing (ECR). In times of need, C2 arranged for an ECR line of credit that took many forms such as overdraft protection, demand loan, export packing credit, term loan, et cetera.

On the other hand, C3 was only lightly affected by the cash flow risk owing to the liquidity aid from few other projects in hand. In certain permissible circumstances, it was appropriate to balance the tortuous cash flow with the other projects that gave higher yields.

TABLE I: PROFILE OF INTERVIEWEES

\begin{tabular}{clccc}
\hline \hline Code & Designation & Experience in industry (years) & Firm's operation in Malaysia (years) & Firm's operation in Gulf (years) \\
\hline \hline C1 & Senior Manager & 20 & 27 & 5 \\
\hline C2 & Project Executive & 9 & 36 & 3 \\
\hline C3 & Senior Manager & 25 & 30 & 8 \\
\hline \hline
\end{tabular}

TABLE II: Profile of CONSTRUCTION PROJECTS IN THE GULF

\begin{tabular}{|c|c|c|c|c|c|c|}
\hline Code & Location of projects & Type of projects & $\begin{array}{l}\text { Ownership of } \\
\text { facility }\end{array}$ & Selection procedures & Entry mode & $\begin{array}{c}\text { Contract } \\
\text { value }(\mathrm{RM}) \\
\end{array}$ \\
\hline $\mathrm{C} 1$ & Riyadh, Saudi Arabia & Educational & Private & Open tendering & $\begin{array}{l}\text { Wholly owned } \\
\text { foreign subsidiary } \\
\text { firm }\end{array}$ & $334.1 \mathrm{M}$ \\
\hline $\mathrm{C} 2$ & Abu Dhabi, UAE & $\begin{array}{l}\text { Residential, commercial and } \\
\text { recreational; Government } \\
\text { facility }\end{array}$ & $\begin{array}{l}\text { Private; } \\
\text { Government }\end{array}$ & Open tendering & $\begin{array}{l}\text { Wholly owned } \\
\text { foreign subsidiary } \\
\text { firm }\end{array}$ & $\begin{array}{r}470.5 \mathrm{M} ; \\
4.1 \mathrm{M} \\
\end{array}$ \\
\hline $\mathrm{C} 3$ & $\begin{array}{l}\text { Sakhir, Bahrain; } \\
\text { Doha, Qatar; Abu } \\
\text { Dhabi, UAE }\end{array}$ & Government facilities & Government & $\begin{array}{l}\text { Selective tendering; } \\
\text { Selective tendering; } \\
\text { Negotiation }\end{array}$ & Joint venture & $\begin{array}{r}58.0 \mathrm{M} ; \\
2.5 \mathrm{~B} ; \\
4.0 \mathrm{~B}\end{array}$ \\
\hline
\end{tabular}

\section{1) Credit policy}

According to $\mathrm{C} 1$ and $\mathrm{C} 3$, being a new entity in a foreign region (The Gulf) was a huge disadvantage. The records of accomplishment and histories of payment of these construction firms were not acknowledged by the suppliers there. Consequently, $\mathrm{C} 1$ purchased letter of credit from a bank and forwarded it to supplier's bank in return for the supplies of goods on credit. In this way, the letter of credit substituted the creditworthiness of a bank for the creditworthiness of $\mathrm{C} 1$ to facilitate trade. The letter of credit guarantees payment of a specified sum in a specified currency for supplier who supplies materials or goods in predetermined conditions and within fixed timeframe.

It was proposed by $\mathrm{C} 3$ to form joint venture with an experienced Middle East contractor to ease the issues on credit policy with the suppliers. The experienced partner had 
no issues to source goods and materials on credit from past projects' suppliers. Being patron to those regular suppliers; the credibility of the C3's joint venture partner was not an issue.

\section{2) Default of subcontractor, supplier or client}

All the experts showed negative response for the risk of default of subcontractor, supplier or client during the course of the contract. Both $\mathrm{C} 1$ and $\mathrm{C} 2$ managed this risk by conducting background checks on the parties involved. $\mathrm{C} 3$ mentioned that a joint venture partner minimized this risk due to their long-term partnership with the subcontractor and supplier. Building of trust through patronage is benefiting the parties involved in project.

\section{3) Delayed or non-receipt of payment}

At the time of recession and credit crunch, many construction firms were at risk of suffering the effects of delay and non-receipt of payment. It was not foreseen by the interviewees, many succumbed to clients who delayed payments to contractors. The employer of $\mathrm{C} 1$ had insufficient financing, hence delaying few payments. It was thus advised by $\mathrm{C} 1$ the need to include provision in the contract that allowed contractor to suspend work in the event of non-payment. If the employer refused to come into agreement with the contract terms, it would most likely to be a wise choice to not work for them.

C3 had a different approach besides contractual provision as advised by $\mathrm{C} 1$ that was by negotiating with the client. $\mathrm{C} 1$ described that some clients seemed to have certain financial issues, which led to delay in paying interim payment and sometimes final payment. At times, client took opportunity of the financial constraints. To deal with such client, C3 suggested negotiating with the client frequently to maintain good business relationship. C3 also implied that dealing with difficult payment from client was just a matter of time.

\section{4) Financial failures by subcontractor, supplier or client}

In this preliminary study, financial failure by subcontractor, supplier or client was not an issue to all the construction firms. However, $\mathrm{C} 1$ expected a chain reaction from the delayed payment of the client to the subsequent payment from contractor to subcontractor, thereby insinuating the delayed payment of the client was the main culprit. On the other hand, C3 added that it was not predictable for the client to become a bad client from a good client during the unexpected time of recession. The client was unable to pay promptly forcing C3 to collect outstanding payments later.

\section{5) Inadequate financial margins}

Interviewees $\mathrm{C} 2$ and $\mathrm{C} 3$ encountered inadequate financial margins in their Gulf projects. $\mathrm{C} 1$ had no issue with this risk as the profit was incorporated in the properly projected tender price. As for $\mathrm{C} 2$, it was a competitive bid due to open tendering, hence, lowered the financial margins. Nevertheless, the Gulf projects were part of C2's business strategies in order to obtain other overseas projects. The project was not generating profit but these flagship projects enhanced the firm's reputation in the eye of the international construction arena.

Generally, C3 commented that the ventures in the Gulf were not returning high profit, as they were inexperienced and novice in the region. During the competitive tendering process, winning the contract normally signified being the lowest bidder. In order to bid competitively and take into account of the risks in the particular country, C3 mitigated the risk by utilizing the knowledge and advices of their joint venture partner with vast experience in that country.

\section{6) Unbalanced sharing of risks}

All experts agreed that unbalanced sharing of risks existed in the Gulf construction, in which all responsibilities were thrown to the main contractor. $\mathrm{C} 1$ revealed that the main contractor had to be the specialist who knew the engineering know how and many more. $\mathrm{C} 1$ furthered that it had been a norm in Saudi Arabia for the specialists or subcontractors to be amateurish, putting all risks on the contractor. C3 mentioned that contractors took more risks in most contracts. When the client held up the entire fund and refused to pay the contractor, the contractor were susceptible to all the risks. Consequently, the risks were transferred to the subcontractors and other related parties.

\section{B. External Risk- Economic Aspect}

1) Material, equipment, and manpower supply-availability or price fluctuation

All three contractors imported their materials, equipments and manpower due to the limited supply. In the case of $\mathrm{C} 1$, they imported their materials and equipments from other places for instance Qatar, China or countries with supplies. Badouri (2007) pointed out the other overseas building material exporters were European Union, Turkey, South Korea, Indonesia, Malaysia and China due to the limited local production of building materials in terms of quantity and variety in the Middle East [22].

$\mathrm{C} 1$ also recalled the construction boom in the year 2008 not only caused a shortage of materials for instance lacked of steels, but also manpower, leading to increase in prices of construction materials and manpower in the region. For that reason, all contractors succumbed to importing expatriates and blue-collar foreign labours like Bangladeshis, Indians, Pakistanis, Filipinos, Malaysians, and Africans, hence forming multinational workers.

\section{2) Inflation rates volatility}

Both $\mathrm{C} 1$ and $\mathrm{C} 2$ did not encounter the inflation rates volatility during the course of their Gulf constructions. In the case of $\mathrm{C} 3$, the current projects were not much affected by inflation but it had happened few years back in 2008. The contracts were fixed price contract without the insertion of fluctuation clause, which transferred the inflation rates volatility risk to the main contractor.

\section{3) Fluctuation in foreign exchange rates}

The head of currency hedge fund urged Gulf states to drop United State Dollar (USD) peg to avoid being vulnerable to United States shocks [23]. To date, Kuwait is the only to have scrapped its dollar peg among the Gulf states.

C1 dealt their contracts in Saudi Riyal (SR), the same currency as their revenues. Since the Saudi Riyal is pegged to the USD, their revenues in the currency of SR depended on the USD. The fluctuation was tolerable in more or less of 5 percent. On the other hand, C3 managed their contracts in USD and the fluctuation was also acceptable. The contractors accepted the risk of fluctuation in exchange rates due to the 
slight fluctuation.

\section{4) Economic recession}

The data from the Economist Intelligence Unit (2010) indicated the slowdown of the Gulf economy had begun in the latter part of 2008, spilling over into 2009, when the global recession hit the UAE hard [24]. Consequently, there was a sharp slowdown in the construction activity. All three contractors were affected by this slowdown, suffering from delayed payments from the client. Nonetheless, C3 was optimistic with the situation and commented that the Gulf, especially the oil producers, were still moving as they needed to expand its Gross Domestic Product (GDP) and to maintain their positions as one of the largest economies in the world.

\section{CONCLUSION}

This preliminary study, which serves as an indication on the Gulf scenario, found that the financial risks had more influences on the Malaysian construction firms instead of the economic risks. On the financial aspect, the construction firms had to be financially robust by setting aside sufficient sum of internal reserve funds to counter the risks like 'delayed or non-receipt of payment from client' and 'interest rate volatility'. Forming partnership with a local partner firm could also provide useful information like appointing the reliable subcontractors and obtaining the credit terms from familiar the suppliers. In the context of economic aspect, the Gulf Cooperation Council (GCC) governments spending policies highly dependent on migrant manpower to implement their government spending policies, thus minimal restrictions on various aspects.

\section{REFERENCES}

[1] S. H. Han and J. E. Diekmann, "Making a risk-based bid decision for overseas construction projects," Construction Management and Economics, vol. 19, pp. 765-776, 2001b.

[2] S. H. Han, J. E. Diekmann, and J. H. Ock, "Contractor's risk attitudes in the selection of international construction projects," Journal of Construction Engineering and Management, vol. 131, no. 3, pp. 283-292, March 2005.

[3] F. Y. Y. Ling and S. P. Low, "Legal risks faced by foreign architectural, engineering, and construction firms in China," Journal of Professional Issues in Engineering Education and Practice, vol. 133, no. 3, pp. 238-245, July 2007.

[4] Construction Industry Development Board. Number and value of projects undertaken by Malaysian contractors in global market by year of project awarded. Kuala Lumpur: Construction Industry Development Board; 2010.
[5] S. B. Naceur and C. Labidi, Middle East and North Africa region: Financial sector and integration; n.d. Retrieved June 15, 2010, available: QFINANCE: http://www.qfinance.com

[6] The World Bank, Economic developments and prospects: Job creation in an era of high growth. Washington: The International Bank for Reconstruction and Development; 2007.

[7] H. Zhi, "Risk management for overseas construction projects," International Journal of Project Management, vol. 13, no. 4, pp. 231-237, 1995.

[8] J. G. Perry and R. W. Hayes, "Risk and its management in construction projects," in Proceedings of Institution of Civil Engineers, 1985, pp. 499-521.

[9] M. A. Mustafa and J. F. Al-Bahar, "Project risk assessment using the analytic hierarchy process," IEEE Transactions on Engineering Management, vol. 38, no. 1, pp. 46-52, 1991.

[10] S. Q. Wang, L. K. Tiong, S. K. Ting, and D. Ashley, "Evaluation and management of foreign exchange and revenue risks in China's BOT projects," Construction Management and Economics, vol. 18, pp. 197-207, 2000.

[11] C. O. Egbu and Z. Serafinska, "Attitudes to risk management in diverse project environments," in COBRA Conference, Greenwich: RICS Research Foundation, 2000, pp. 1-10.

[12] S. H. Han and J. E. Diekmann, "Approaches for making risk-based go/no-go decision for international projects," Journal of Construction Engineering and Management, vol. 127, no. 4, pp. 300-308, July/August 2001a.

[13] L. Tchankova, "Risk identification- Basic stage in risk management," Environmental Management and Health, vol. 13, no. 3, pp. 290-297, 2002.

[14] L. Bing, A. Akintoye, P. J. Edwards, and C. Hardcastle, "The allocation of risk in PPP/PFI construction projects in the UK," International Journal of Project Management, vol. 23, no. 1, pp. 25-35, 2005.

[15] F. Y. Y. Ling and L. Hoi, "Risks faced by Singapore firms when undertaking construction projects in India," International Journal of Project Management, vol. 24, no. 3, pp. 261-270, 2006.

[16] F. Y. Y. Ling and H. L. Lim, "Foreign firms' financial and economic risk in China," Engineering, Construction and Architectural Management, vol. 14, no. 4, pp. 346-362, 2007.

[17] S. M. El-Sayegh, "Risk assessment and allocation in the UAE construction industry," International Journal of Project Management, vol. 26, pp. 431-438, 2008.

[18] D. Baloi and A. D. Price, "Modelling global risk factors affecting construction cost performance," International Journal of Project Management, vol. 21, no. 4, pp. 261-269, 2003.

[19] J. W. Creswell, Research design: Qualitative, quantitative, and mixed methods approaches; California: Sage Publications, 2009.

[20] K. Krippendorff, Content analysis: An introduction to its methodology; California: Sage Publications, 1980.

[21] Construction Industry Development Board. Malaysian construction industry directory (MCID) 2008-2009. Kuala Lumpur: Construction Industry Development Board; 2009.

[22] S. Badouri, "Construction boom in UAE \& Saudi Arabia: Opportunities for Asian companies," in Master Builders 3rd Quarter, pp. 80-92, 2007.

[23] Business Intelligence Middle East. Gulf states should drop Dollar peg, says head of currency hedge fund; 2010. Retrieved April 5, 2010, from Business Intelligence Middle East: [Online], available: http://www.bime.com/main.php? $\mathrm{c}=3 \& \mathrm{cg}=2 \& \mathrm{t}=1 \& \mathrm{id}=44740$

[24] Economist Intelligence Unit. Economic country outlooks-Middle East; 2010. Retrieved June 3, 2010, available Intelligence Quarterly: http://www.intelligencequarterly.com/2010/05/economic-countryoutlc oun-middle-east 